\title{
Identification of Groundwater Potential using Schlumberger Array of Resistivity Method in Bulukumba South Sulawesi
}

\author{
Agussalim ${ }^{1, a,{ }^{,}}$and Nur Ichzan $\mathrm{AS}^{1, \mathrm{~b}}$ \\ ${ }^{1}$ Department of Mathematics and Science, Universitas Muslim Maros, Maros \\ *,a agussalim@umma.ac.id \\ bnurichzanas@umma.ac.id
}

\begin{abstract}
The research was carried out in Bontorannu Village, Kajang District, Bulukumba Regency, South Sulawesi. The research area is a plain area with rainfed rice fields. Therefore, it is necessary to do research to identify the potential of groundwater as a source of irrigation. The purpose of this research is to provide an estimate of the plane, position, and depth of the aquifer layer in the soil based on the interpretation of measurements using the resistivity method of the Schlumberger array. Through the results of this interpretation, the pattern/contour modeling of the distribution of the aquifer layer in the soil is determined which is projected as groundwater. This research is an experimental research with a descriptive approach method. Methods of this research consists of research preparation, data acquisition, processing and interpretation of data using Res2dinv software. The measurement points were selected through feasibility survey. There are two measurement points that length of each track used is a maximum of $\mathbf{3 0 0}$ meters. The results showed that on track 1 there is a layer suspected of being a shallow aquifer with a depth of $12-22 \mathrm{~m}$. While on track 2 , a potential deep aquifer layer is detected with a depth of 13-25 m.
\end{abstract}

Keywords- groundwater, irrigation, resistivity methods, Schlumberger array, Res2dinv

\section{Introduction}

Bontorannu is one of the villages that is located in Kajang District, Bulukumba Regency, South Sulawesi. Most of the rice fields in Bontorannu are rainfed rice fields that are harvested once a year. Rainfed agriculture relies rainfall for water supply. This results in agricultural production that is not optimal. The irrigation system is not supported by flow from water sources such as rivers or reservoirs so that groundwater exploration is needed as a source of irrigation water.

Groundwater occupies the voids in the geological layer in a saturated state and in sufficient quantities (identical to aquifers) [1]. In the dry season, groundwater can be an alternative because surface water and rainwater cannot meet irrigation water needs. The irrigation water requirement for rice crops is different from that for secondary crops, where the ratio of water requirements for rice plants can reach two to four times the water requirements for secondary crops [2]. Therefore, it is necessary to identify the potential of groundwater that can be used as water in the irrigation system in Bonto Rannu Village, Kajang District, Bulukumba Regency.

There are several methods in geophysical exploration for groundwater including magnetic, seismic, gravitational, electromagnetic, and geoelectric methods [3]. One of the geophysical methods commonly used in groundwater research is the resistivity method. This method is considered as one of the most potential methods in groundwater exploration [4], [5], [6]. The resistivity method or the resistivity geoelectric method is a dynamic method because it uses active interference through current electrodes in the form of current injection that is emitted below the earth's surface [7], [8]. The resistivity method provides an overview of the composition and depth of rock layers by measuring the electrical properties of the rock. Geoelectric survey with resistivity method can be done in two ways, namely mapping and sounding which produces information on changes in the variation of resistivity values in both lateral and vertical directions [9].

There are two types of resistivity probes, namely Horizontal Profiling (HP) and Vertical Electrical Sounding (VES) or depth probes [10]. The VES method aims to study the characteristics and mapping of aquifer 
layers and estimate groundwater content, and can be used as a guide in groundwater drilling [11]. The results of the current and potential difference measurements from the VES resistivity method for each particular electrode distance can be determined by the variation of the resistivity value of each layer below the measuring point (sounding point). The difference in the resistivity value of the material below the surface will be captured by the potential electrode [7].

Electrical resistivity is related to different subsurface characteristics, which include porosity, density, pore size, shape, temperature, degree of water saturation in rocks and so on. By considering some of these factors, the groundwater conditions in an area can be interpreted [11], [12]. The resistivity method is more cost-effective and efficient so that groundwater exploration becomes more practical because abundant and clean aquifer layers can be more easily detected [10], [13], [14], [15].

The design of the resistivity method in this research was applied with the Schlumberger array. The Schlumberger array is a sounding technique, the distance between the current and the electrode varies, so that only the current is moved. This configuration is most often used to find water sources [16].

The Schlumberger array (Figure 1) consists of two current electrodes (C) and one potential electrode (P) which are placed symmetrically between the two current electrodes at a much larger interval than the two potential electrodes [17], [18].

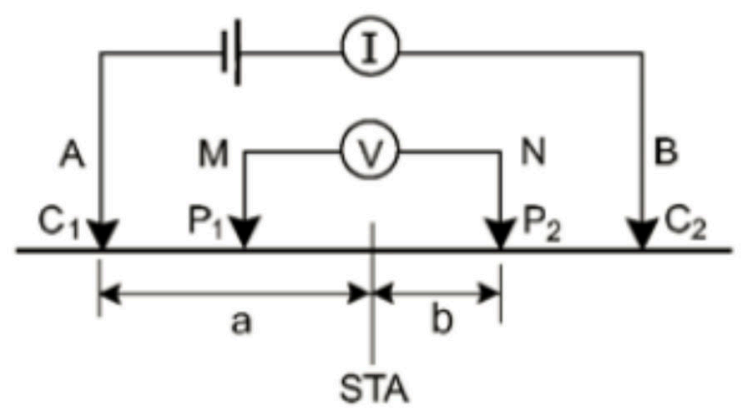

Figure 1. The Schlumberger array of electrodes [19]

The equation used in the Schlumberger array is as follows [11]:

$$
\rho a=\pi\left(b^{2} / 2-a / 4\right) \frac{V}{I}
$$

The Schlumberger method is easy to operate, as it takes less time and deeper distances can be covered. Depths of more than $100 \mathrm{~m}$ can be reached by this method [12], [17].
The purpose of study is to provide an estimate, position, and depth of the aquifer layer in the soil based on the interpretation of measurements using the resistivity method with Schlumberger array. Through the results of this interpretation, the pattern/contour modeling of distribution of aquifer layers in the soil is determined. Previous research in 2019 by Puspitasari, et al [20] and Syamsuddin, et al [8] discussed the geoelectrical resistivity method to explore groundwater potential in the South Sulawesi region. Based on the various research results, it can be seen that the geological conditions of the subsurface layer can be predicted using the resistivity method.

The topography of the research area is plains or rice fields. In accordance with the hydrological map, the position of groundwater in the rice fields in Bonto Rannu is deep enough so that an optimal vertical resistivity method is needed. Previous research by Ezema et al [12] using the Schlumberger configuration showed that this method can reach aquifer layers up to hundreds of meters. Therefore, to explore and utilize groundwater as a source of agricultural irrigation, this research was conducted by identifying the potential for groundwater in Bontorannu, Bulukumba Regency.

\section{Research Methodology}

\section{A. Method}

This type of research is an experimental research with a descriptive approach method. The research location is in Bontorannu Village, Kajang District, Bulukumba Regency, which is located in South Sulawesi Province. The research was conducted from July to September 2021 where the data acquisition process took place on August 4-5, 2021.

\section{B. Figure and Table}

The research data are in the form of primary data and secondary data. Primary data retrieval was carried out using the Schlumberger array resistivity method with a measurement path length of $300 \mathrm{~m}$. The trajectories used in this study were two trajectories which were obtained through a site feasibility survey before the research was conducted. The two tracks were chosen with consideration of accessibility and the strategic position of the research location covering a lot of rice fields in the vicinity. Primary data processing using Res2div software. 


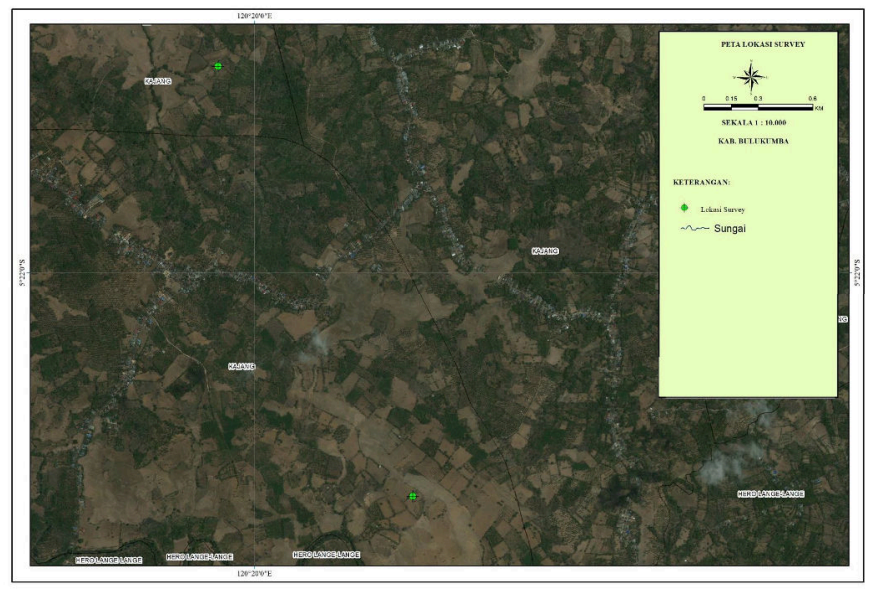

Figure 2. Satellite Image of the Research Location

Based on Figure 2, the topographical conditions of the research location are in the form of rice fields/plains. The description of the research location in terms of the satellite image map is shown in Table 1.

Table 1. Location and Condition of Survey Track

\begin{tabular}{|l|l|l|l|l|l|l|l|c|l|}
\hline \multirow{2}{*}{ Track } & \multicolumn{3}{|c|}{ Coordinate (S) } & \multicolumn{3}{c|}{ Coordinate (E) } & \multirow{2}{*}{$\begin{array}{c}\text { Terrain } \\
\text { Conditions }\end{array}$} & Formation \\
\cline { 2 - 7 } & Degree & Minutes & Seconds & Degree & Minutes & Seconds & & \\
\hline 1 & 1 & 37 & 74 & 120 & 34 & 17 & Plains & $\begin{array}{l}\text { Tmpw: } \\
\text { Formation } \\
\text { Walanae }\end{array}$ \\
\hline 2 & 5 & 21 & 23,3 & 120 & 19 & 53,5 & Plains & $\begin{array}{l}\text { Tmpw: } \\
\text { Formation } \\
\text { Walanae }\end{array}$ \\
\hline
\end{tabular}

There are two tracks with different coordinates as shown in Table 1. Refer to Table 1, the coordinates of first track is $1^{\circ} 37^{\prime} 74 " \mathrm{~S} 120^{\circ} 34^{\prime} 17^{\prime \prime} \mathrm{E}$. For the second track, the coordinates is $5^{\circ} 22^{\prime} 0^{\prime \prime} \mathrm{S} 120^{\circ} 20^{\prime} 0^{\prime \prime} \mathrm{E}$. Both tracks are plain areas.

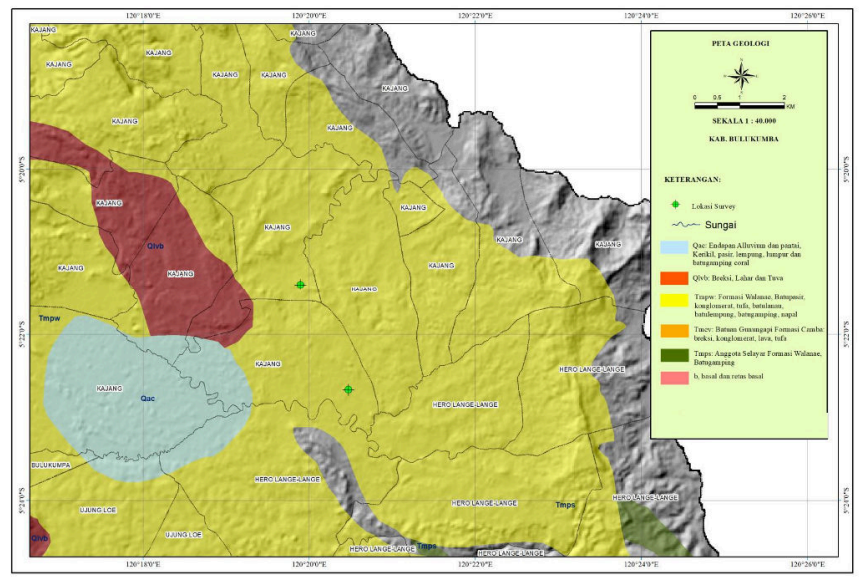

Figure 3. Geological Map of Kajang
Secondary data that supports the results of the study is a geological map of the research location (Figure 3). Bontorannu Village, Kajang District, located in Bulukumba Regency is composed of the Walanae Formation (Tmpw), sandstone, conglomerate, tuff, siltstone, claystone, limestone, and marl. The relative age of the formation and the rocks contained in the Tpmw formation is in the Miseon period.

The research begins with the determination of the coordinates of the research location for each trajectory. It is expected that these two tracks can represent the survey area. Tools and materials used for data acquisition are resistivity meter, hammer, electrode rod, meter, handytalkie, cable and Schlumberger data sheet. Here are the stage of experimental research as shown in Figure 4.

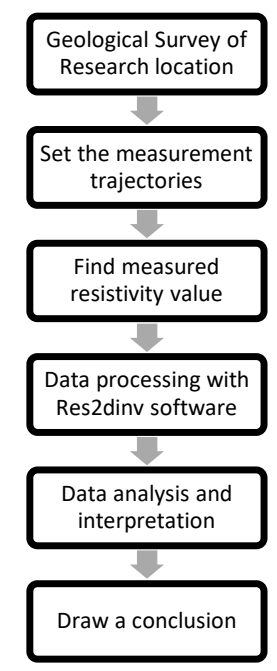

Figure 4. Research Flowchart

This research begins with determining the coordinates of the location and preparing the tools and materials to be used for data retrieval or acquisition. The data acquisition process is carried out on a track that has been prepared at the research site to obtain the apparent subsurface resistivity. This stage is carried out by installing electrodes and placing them parallel in a straight line, then the electrodes are connected to the Tigre Campus Resistivity meter.

The principle of the geoelectric method by injecting DC electric current into the ground. Connect the resistivity meter to the electrodes. This electric current injection uses 2 current electrodes $\mathrm{A}$ and $\mathrm{B}$ which are plugged into the ground with a certain distance. The longer the electrode distance $\mathrm{AB}$ will cause the flow of 
electric current to penetrate deeper layers of rock. With the flow of electric current, it will cause electrical voltage in the ground. The electrical voltage that occurs at the ground surface is measured using a multimeter which is connected through 2 "voltage electrodes" M and $\mathrm{N}$ which are shorter than the electrode distance $\mathrm{AB}$.

The result of resistivity value is recorded in the Schlumberger data sheet for each path. The resistivity value obtained is the apparent resistivity value. The apparent resistivity value obtained is then processed so that it becomes the actual resistivity value.

Knowing the current and voltage values, the apparent resistivity value can be calculated. This value is then multiplied by $k$ (geometry factor) to get the actual resistivity value and then inverted through the Res2dinv for later interpretation.

\section{The Basic Concept of Apparent Resistivity}

The measured resistivity value is known as apparent resistivity. The earth consists of several layers that have different resistivity $(\rho)$ values, so the measured potential difference is the influence of these layers. This gives a measured resistivity value not only for one layer, but for all layers [7]. The apparent resistivity value is expressed in the following equation [21]:

$$
\rho_{a}=k \frac{\Delta V}{I}
$$

Thus, the measured resistivity value is not the actual resistivity, but the apparent resistivity. The actual resistivity value is obtained through the inversion process of the apparent resistivity value [22].

\section{E. Inversion Theory}

The inversion process in geophysics aims to find a model that provides a response similar to the measurement value so that the type of model is obtained which is an ideal mathematical representation of a part of the earth. The physical quantity to be estimated from the observed data is a set of parameters owned by the model. The parameter part of the model is the resistivity value of the cell model, while the data is the measured apparent resistivity value [7]. In the inversion process for resistivity studies, the logarithm of the model response and the apparent resistivity value of the observation data are used. In the cell-based method used is Res2dinv. 2D data processing through Res2dinv software using inversion modeling. The inversion in Res2dinv is a process of modeling the actual resistivity value based on the apparent resistivity value [18].

\section{F. Groundwater}

Groundwater occupies rock pores below the soil surface in the saturated zone and in sufficient quantities. Groundwater is found in several geological types, and one of the most important is the aquifer. Examples of aquifer rock formations are incompressible sand, gravel, limestone, sandstone, dolomite, basalt flow, metamorphic rock, and plutonic with many adhesions. The nature of the aquifer to be able to store groundwater is called porosity or porosity, while the property of the aquifer to pass groundwater is called permeability. These two properties affect the availability of groundwater in a geological zone [1], [23].

Groundwater classification based on depth is divided into overburden and aquifer layers. The overburden layer is the layer above the aquifer and is deficient and does not pass water whose resistivity ranges from $<45 \Omega$ meter, while the aquifer is a layer of rock and water that is permeable and has a resistivity of $45-350 \Omega$-meter [11]. The content contained in the subsurface structure is interpreted based on color images that describe the distribution of resistivity below the surface. The data interpretation process is carried out by looking at the characteristics of the resistivity values obtained from the modeling results from the Res2Dinv software based on the conversion table for the resistivity values of several rock types. From the interpretation of the data, it is obtained an alleged description of the position and depth of the aquifer layer which is projected as groundwater.

\section{Results and Discussion}

The process of acquiring subsurface apparent resistivity data is carried out at the coordinates of the path that has been determined at the research location. The results of resistivity measurements depicted in geological sections (Figures 5 and 6) show the lithological composition of the Bontorannu area, Kajang District, Bulukumba Regency. The following is the result of data interpretation showing the subsurface content of the study area. The distribution of subsurface resistivity on both paths is in the range of 1.54 to 21084 $\Omega \mathrm{m}$ which is depicted by color images in 2D crosssection as shown in Figures 5 and 6. 
a. Track 1

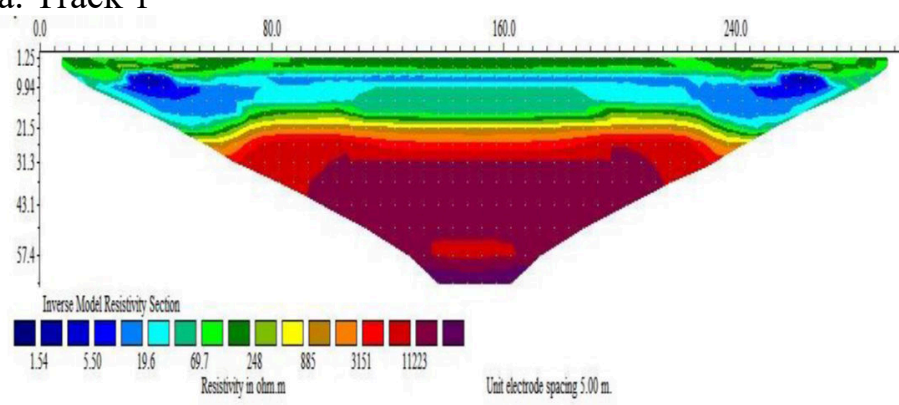

Figure 5. 2D cross section resistivity value and the depth of track 1

The maximum depth of track 1 is 57.4 meters. From the measurement results, the apparent resistivity range ( $\rho$ ) of the soil/rock layer is between $1.54-11223 \Omega \mathrm{m}$.

\section{b. Track 2}

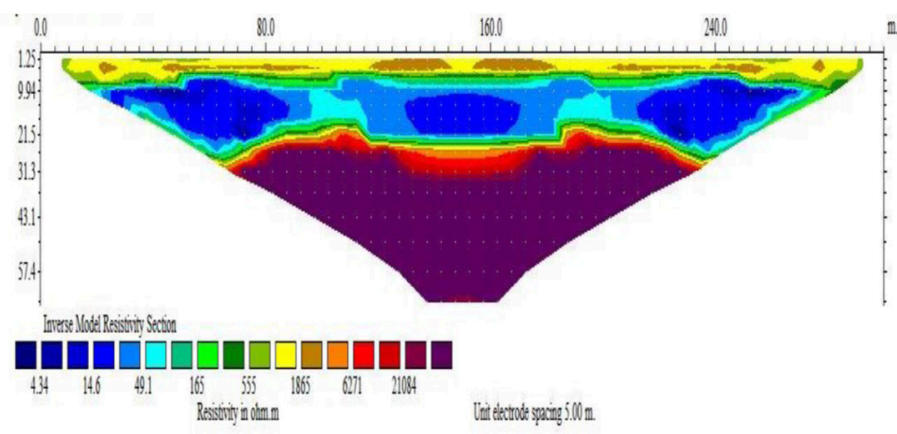

Figure $6.2 \mathrm{D}$ cross section resistivity value and 2 track depth

Track 2 with a measuring track length of 300 meters and a maximum depth of 57.4 meters. From the measurement results, the apparent resistivity range $(\rho)$ of the soil/rock layer is between $4.34-21084 \Omega \mathrm{m}$.

Table 2. Interpretation of Resistivity Value

\begin{tabular}{|l|l|l|ll|}
\hline Track & $\begin{array}{c}\text { Soil/rock } \\
\text { layer }\end{array}$ & \multicolumn{1}{|c|}{$\begin{array}{c}\text { Resistivity } \\
\text { value }\end{array}$} & \multicolumn{1}{|c|}{ Description } \\
\hline 1 & Layer 1 & $0-100 \Omega \mathrm{m}$ & $\begin{array}{l}\text { Possibility of } \\
\text { groundwater }\end{array}$ \\
\cline { 2 - 5 } & Layer 2 & $100-11223 \Omega \mathrm{m}$ & Hard volcanic rock \\
\hline 2 & Layer 1 & $0-100 \Omega \mathrm{m}$ & $\begin{array}{l}\text { Possibility of } \\
\text { groundwater }\end{array}$ \\
\cline { 2 - 5 } & Layer 2 & $100-21084 \Omega \mathrm{m}$ & Hard volcanic rock \\
\hline
\end{tabular}

In general, in track 1, it can be divided into 2 (two) parts, namely the first layer with a resistivity value between 0 - $100 \Omega m$ (blue - light green) where groundwater is suspected and the sandstone layer with a depth of $12-22 \mathrm{~m}$. The second layer with resistivity values of $100-11223 \Omega \mathrm{m}$ (dark green - purple) is thought to be a layer of hard Lompobattang volcanic rock breccia at a depth of $23-57.4 \mathrm{~m}$.

For track 2, this layer can be divided into 2 (two) parts. The first layer with a resistivity value between 0 $100 \Omega \mathrm{m}$ (dark blue - light blue) is predicted to contain groundwater and a layer of sandstone with a depth of 13 - $25 \mathrm{~m}$. Meanwhile, the second layer with resistivity values of $100-21084 \Omega \mathrm{m}$ (dark green - purple) is predicted to be a compact and hard Lompobattang volcanic rock breccia layer at a depth of $26-57.4 \mathrm{~m}$.

The results of the interpretation of resistivity data from the study area indicate that it is suspected that there is an aquifer layer containing groundwater. This aquifer layer is found in a shallow aquifer layer located above a depth of $50 \mathrm{~m}$ bmt (below ground level) [24], [25].

The aquifer layer on track 1 is at a depth of $10-20 \mathrm{~m}$ below the soil surface covered by a layer of sandstone. The aquifer layer on track 1 extends from a distance of $30 \mathrm{~m}$ to $280 \mathrm{~m}$. While the aquifer layer on track 2 is at the same depth as the aquifer layer on track 1, which is at a depth of 10-20 m below the surface. Groundwater in this aquifer can be utilized optimally as a source of agricultural irrigation because of the shallow depth and softer sandstone layer making it easier to explore.

Based on the geological map, the research location includes the Walanae formation. The Bontorannu area, Bulukumba is composed of sedimentary rock material for the Walanae Formation (Tmpw), Lompobattang volcanic rock, sandstone, conglomerate, tuff, siltstone, claystone, limestone, and marl. The rocks in the Walane Formation are mostly siliciclastic rocks in the form of sandstone [26]. The aquifer layer on both paths includes an unconfined aquifer layer with the top layer composed of a layer of sandstone [27]. The interpretation of the data on the alleged aquifer layer in the subsurface layer of Bontorannu village is possible from the rock properties in the Walanae Formation which show a number of sandstone outcrops that have porosity/watercarrying potential [28]. Based on Figures 5 and 6, the aquifer layer is bounded by a layer of sandstone. This rock type has good porosity and can potentially be a reservoir rock [29].

\section{Conclusion}

The results of data interpretation to predict groundwater in Bontorannu village, Herlang sub-district, Bulukumba district, show that on the track 1 there is a 
layer suspected of being a shallow aquifer with a depth of $12-22 \mathrm{~m}$. While on the track 2 , a potential deep aquifer layer is detected with a depth of 13-25 m.

\section{Acknowledgement}

This research is a PDP research funded by DRPM Ministry of Education, Culture, Research and Technology.

\section{References}

[1] Bisri, M., "Air Tanah : Studi Tentang Pendugaan Air Tanah, Sumur Air Tanah, dan Konsevasi Air Tanah", (Groundwater: Study on Estimating Groundwater, Groundwater Wells, and Groundwater Conservation), Jilid 1. Malang: Tim UB Press. 2012.

[2] Kementerian Pekerjaan Umum dan Perumahan Rakyat, "Modul 3 : Modul Pengetahuan Umum Irigasi, Pelatihan Operasi dan Pemeliharaan Irigasi Tingkat Juru", (Module 3: General Knowledge of Irrigation Module, Interpreter Level Irrigation Operation and Maintenance Training), sdm.pu.go.id/center/pelatihan/uploads/edok/2019/02/048d4 MD L Pengetahuan Umum Irigasi.pdf . 2017.

[3] Kementerian Pekerjaan Umum dan Perumahan Rakyat, "Modul 4 Eksplorasi Geofisika Untuk Air Tanah, Pelatihan Teknologi Geolistrik 2 Dimensi untuk Perencanaan Pemanfaatan Potensi Air Tanah", (Module 4: Geophysical Exploration for Groundwater, 2-Dimensional Geoelectric Technology Training for Planning for Utilization of Groundwater Potential), https://simantu.pu.go.id/epel/edok/e94f7 4. Modul_Eksplorasi Geofisika untuk Airtanah.pdf. 2019.

[4] Mahmoud, I., Mohamaden, \& Ehab, D., "Application of electrical resistivity for groundwater exploration in Wadi Rahaba, Shalateen, Egypt". NRIAG Journal of Astronomy and Geophysics 6 (2017) 201-209. 2017.

[5] Bayewu, O. O., et.al., "Assessment of groundwater prospect and aquifer protective capacity using resistivity method in Olabisi Onabanjo University campus, Ago-Iwoye, Southwestern Nigeria”. NRIAG Journal of Astronomy and Geophysics, 7. pp. 347-360. 2018. https://doi.org/10.1016/j.nrjag.2018.05.002. 2018.

[6] Gijoh, O. T., As'ari, Pasau, G., "Identifikasi Akuifer Air Tanah Menggunakan Metode Geolistrik Tahanan Jenis Konfigurasi Dipol-Dipol di Masjid Kampus Universitas Sam Ratulangi”, (Identification of Groundwater Aquifers Using the Geoelectrical Method of Dipole-Dipole Configuration Type at the Mosque of Sam Ratulangi University Campus). JURNAL MIPA UNSRAT ONLINE Vol. 6, No. 1. pp. 17-20. 2017.

[7] Agussalim, "Aplikasi Metode Resistivitas Konfigurasi Wenner untuk Menafsirkan Penyebaran Batuan Situs Purbakala Candi Gambar Wetan Kabupaten Blitar", (Application of Wenner Configuration Resistivity Method to Interpret Rock Distribution at Archaeological Site Gambar Wetan Temple in Blitar), (Tesis). Surabaya : Institut Teknologi Sepuluh November. 2015.

[8] Syamsuddin, E., et.al., "Application of Geoelectrical Resistivity Method for Groundwater Exploration Using WennerSchlumberger Configuration in Sampakang, Maros Regency, Indonesia". The 3rd International Conference On Science, Journal of Physics: Conference Series 1341. 2019. 082046 IOP Publishing doi:10.1088/1742-6596/1341/8/082046. 2019.
[9] Hakim, A., \& Hairunisa, H., "Survey Geofisika Metode Geolistrik Resistivitas Untuk Menentukan Struktur Bawah Permukaan Desa Rada Kecamatan Bolo Kabupaten Bima", (Geophysical Survey Geoelectric Resistivity Method to Determine the Subsurface Structure of Rada Village, Bolo District, Bima Regency), National Conference on Mathematics, Science and Education (NACOMSE), 1(01), 103-108. 2018.

[10] Broto, S \& Afifah, R., "Pengolahan Data Geolistrik dengan Metode Schlumberger", (Geoelectrical Data Processing with the Schlumberger Method), TEKNIK - Vol. 29 No. 2. 2008.

[11] Heryani, N., Karatiwa, B., \& Sosiawan, H., "Pemetaan Potensi Air Tanah untuk Mendukung Pengembangan Pertanian Lahan Kering", (Mapping the Potential of Groundwater to Support the Development of Dryland Agriculture), Jurnal Sumberdaya Lahan Vol. 8 No. 2, Desember 2014; 95-106 ISSN 1907-0799. 2014.

[12] Ezema, O.K., Ibout, J.C., \& Obiora, D. N., "Geophysical Investigation of Aquifer Repositories in Ibagwa Aka, Enugu State, Nigeria, Using Electrical Resistivity Method". Groundwater for Sustainable Development 11. 100458 https://doi.org/10.1016/j.gsd.2020.100458. 2020.

[13] Agussalim., "Application Of Resistivity Method Wenner Configuration For Interpreting the Spread Of Rock Archaelogical Sites Gambar Wetan Temple District Blitar". Proceeding of The 5th Annual Basic Science International Conference ISSN 2338-0128 Volume 5. 2015.

[14] Azhar,A. T., et.al. "The Use of Electrical Resistivity Method to Mapping The Migration of Heavy Metals by Electrokinetic". IOP Conference Series: Materials Science and Engineering Volume 226. 2017.

[15] Puspitasari, N. D., et.al., "Subsurface prediction using resistivity method (Case study: Bira, South Sulawesi, Indonesia)". Journal of Physics: Conference Series. Volume 1341, Issue 8. 2019.

[16] Kementerian Pekerjaan Umum dan Perumahan Rakyat, "Modul 5 Desain Survei Geolistrik untuk Air Tanah, Pelatihan Teknologi Geolistrik 2 Dimensi untuk Perencanaan Pemanfaatan Potensi Air Tanah", (Module 5: Geoelectrical Survey Design for Groundwater, 2D Geoelectric Technology Training for Planning of Groundwater Potential Utilization). 2019.

[17] Vasantrao, B. M., et.al., "Comparative study of Wenner and Schlumberger Electrical Resistivity Method for Groundwater Investigation: A Case Study from Dhule District (M.S.), India”. Applied Water Science Volume 7, pages 4321-4340. 2017.

[18] Arifianto, I., Savitri, K.P., Priana, M. R. F., \& Setianto, A., "Groundwater exploration in volcanic morphology using geophysical schlumberger resistivity method, in Jeneponto, South Sulawesi Province". Proceedings of the 13th SEGJ International Symposium. 2018.

[19] Maemuna S., Darsono., \& Legowo, B., "Identifikasi Akuifer di Sekitar Kawasan Karst Gombong Selatan Kecamatan Buayan Kabupaten Kebumen dengan Metode Geolistrik Schlumberger", (Identification of Aquifers Around the South Gombong Karst Area, Buayan District, Kebumen Regency with the Schlumberger Geoelectric Method), Jurnal Fisika dan Aplikasinya, Vol 13 Nomor 2. 2017.

[20] Puspitasari, N. D., et.al., "Subsurface prediction using resistivity method (Case study: Bira, South Sulawesi, Indonesia)". Journal of Physics: Conference Series. Volume 1341, Issue 8. 2019.

[21] Lowrie, W., "Fundamental of Geophysics (Second Edition)". New York: Cambridge University Press. 2007.

[22] Telford, W.M., Geldart, L.P., \& Sheriff, R.E., "Applied Geophysics”. London: Cambridge University Press. 1990.

[23] Santosan, L. W., \& Adji, T.N., "Karakteristik Akuifer dan Potensi Airtanah Graben Bantul", (Aquifer Characteristics and Groundwater Potential of Graben Bantul), Yogyakarta : UGM Press. 2014. 
[24] Tonggiroh, A., et.al., "Sosialisasi Pemanfaatan Air Tanah Untuk Lahan Pertanian dengan Metode JIAT Daerah Pallantikang, Kabupaten Bantaeng", (Dissemination of Groundwater Utilization for Agricultural Land with JIAT Method in Pallantikang District, Bantaeng Regency), TEPAT Jurnal Teknologi Terapan untuk Pengabdian Masyarakat Volume 3, Nomor 2. 2020.

[25] Hadian, M.S.D., Mardiana, U., \& Abdurahman, O., "Sebaran akuifer dan pola aliran air tanah di Kecamatan Batuceper dan Kecamatan Benda Kota Tangerang, Propinsi Banten", (Distribution of aquifers and groundwater flow patterns in Batuceper District and Benda District, Tangerang City, Banten Province), Jurnal Geologi Indonesia, Vol. 1 No. 3 September 2006: 115-128. 2006.

[26] Ardiansyah, M., Farida, M., \& Irfan, U. R., "Studi Provenance Batupasir Formasi Walanae Daerah Lalebata Kecamatan Lamuru Kabupaten Bone Provinsi Sulawesi Selatan", (Provenance Study of Sandstone of Walanae Formation, Lalebata Region, Lamuru District, Bone Regency, South Sulawesi Province), Jurnal GEOSANIS Vol. 11 No. 01. 2015.
[27] Santoso, B., Prirahmayang,N., \& Kirana, K. H., "Identification Of Aquifer Using Geoelectric Resistivity Method Of Reciprocal Schlumberger Array (Case Study: Tanggamus, Lampung Province)". IOP Conf. Ser.: Earth Environ. Sci. 311012059. 2019.

[28] Ramli, M., -, S., A, A., Nur, I., Thamrin, M., \& Widodo, S., "Survei Geolistrik untuk Pengembangan Irigasi Air Tanah di Kelurahan Lamatti Rilau - Sinjai, Sulawesi Selatan", (Geoelectric Survey for Groundwater Irrigation Development in Lamatti Rilau Village - Sinjai, South Sulawesi), JURNAL TEPAT : Applied Technology Journal for Community Engagement and Services, Vol. 1, No. 2, 137-146. 2018.

[29] Firmansyah, Y., Mardiana, U., Kurniawan, E., Nurdrajat, Gani, R., "Nilai Dan Jenis Porositas Batupasir Pada Formasi Walatdi Daerah Cicantayan, Kabupaten Sukabumi Berdasarkan Metode Petrografi", (Value and Type of Sandstone Porosity in the Walat Formation in Cicantayan Region, Sukabumi Regency Based on Petrographic Methods), Bulletin of Scientific Contribution: GEOLOGY, Volume 16, No. 3, Desember 2018 : 163-172. 2018. 